\title{
Cat, Dog and Horse Allergens in Swedish Day Care Centres-Associations with Fractional Exhaled Nitric Oxide (FeNO) among Day Care Centre Staff
}

\author{
Dan Norbäck ${ }^{1}$, Gui-Hong Cai ${ }^{1}$, Ivan $\mathrm{Kreft}^{2}$ \& Gunilla Wieslander ${ }^{1}$ \\ ${ }^{1}$ Department of Medical Sciences, Occupational and Environmental Medicine, Uppsala University, Uppsala \\ University Hospital, 75185 Uppsala, Sweden \\ ${ }^{2}$ Biotechnical Faculty, University of Ljubljana, Jamnikarjeva 101, SI-1000, Ljubljana, Slovenia \\ Correspondence: Dan Norbäck, Department of Medical Sciences, Uppsala University, 75185 Uppsala, Sweden. \\ Tel: 46-18-6113649. E-mail: dan.norback@medsci.uu.se
}

Received: December 17, $2015 \quad$ Accepted: February 10, $2016 \quad$ Online Published: February 29, 2016
$\begin{aligned} & \text { doi:10.5539/gjhs.v8n11p24 } \\ & \text { URL: http://dx.doi.org/10.5539/gjhs.v8n11p24 }\end{aligned}$

\begin{abstract}
Purpose: To study associations between cat, dog and horse allergens in day care centres and fractional exhaled nitric oxide (FeNO), eosinophilic cationic protein (ECP) in serum, lung function $\left(\mathrm{FEV}_{1}\right)$ and dyspnoea in day care centre staff. Totally 62 subjects, all females, from five Swedish day care centres participated (participation rate $90 \%$ ).
\end{abstract}

Methods: Dust was collected by vacuum cleaning and Petri dish sampling and analysed for cat (Fel d 1), dog (Can f 1) and horse (Ecu cx) allergens by ELISA. Dyspnoea was measured on an analogue rating scale. FeNO, serum ECP and symptom ratings were log-transformed. Associations were analysed by linear mixed models, adjusting for personal and home environment factors.

Results: Geometric mean (GM) value for allergens in vacuumed dust were $1199 \mathrm{ng} / \mathrm{g}$ for Fel d 1, $666 \mathrm{ng} / \mathrm{g}$ for Can f 1 and $478 \mathrm{U} / \mathrm{g}$ for Equ cx, respectively. GM value for allergens in Petri dish samples (ng/ $\mathrm{m}^{2}$ per day) was 29.8 for Fel d 1 and 9.1 for Can f 1, respectively. Cat allergen (Fel d 1) were positively associated with FeNO both in vacuumed dust $(\mathrm{p}=0.03)$ and in Petri dish samples $(\mathrm{p}=0.03)$. Dog allergen (Can $\mathrm{f} 1)$ in Petri dish samples was negatively associated with FeNO $(\mathrm{p}=0.02)$. Horse allergen (Equ $\mathrm{cx}$ ) in vacuumed dust was negatively associated with FeNO ( $\mathrm{P}=0.03)$.

Conclusion: Cat, dog and horse allergens were commonly found and cat allergen in day care centres can be a risk factor for lower airway inflammation, measured as FeNO, while dog and horse allergens were associated with lower FeNO.

Keywords: day care centres, cat allergen, dog allergen, horse allergen, fractional exhaled nitric acid (FeNO), indoor environment

\section{Introduction}

Day care centres are important indoor environments for younger children but they can contain different types of environmental pollutants such as formaldehyde, volatile organic compounds (VOC), airborne particles and bacterial compounds (Bröms et al., 2006). Moreover, building dampness and indoor mould growth is common in Swedish day care centres and fungal DNA can be detected in the dust (Cai et al., 2009; Cai et al., 2011a). Cat, dog and horse allergens are common in schools and day care centres and these allergens are transferred by clothes and hair from the home environment by furry pet keepers (Salo et al., 2011; Zahradnik \& Raulf, 2014). In addition, horse allergens has been detected Swedish day care centres (Cai et al., 2011a). Allergy to cat and dogs can be a major health risk for asthma and rhinitis (Konradsen et al., 2015). There has been a focus on the health significance of cat allergen (Fel d 1) in the indoor environment (Kelly et al., 2012). However, allergic sensitization to horse allergens have also been mentioned as an underestimated risk in urban population without occupation exposure to horse allergens (Liccardi et al., 2009).

There are very few studies on associations between indoor exposure in day care centres and respiratory health in day care centre staff. Three older studies from Finland and Taiwan found associations between dampness and 
mould in day care centres and respiratory symptoms among day care centre staff (Ruotsalainen et al., 1995; Li et al., 1997a; Li et al., 1997b). Moreover, we have recently published a study on associations between levels of fungal DNA in Swedish day care centres and respiratory health among day care centre staff (Norbäck et al., 2015). However, we found no previous study on associations between cat, dog or horse allergen levels in day care centres and respiratory health in day care centre staff.

The aim was to study associations between levels of cat (Fel d 1) dog (Can f 1) and horse (Equ cx) allergens in day care centres in mid-Sweden and four health outcomes in day care centre staff; (1) fractional exhaled nitric oxide (FeNO), (2) serum levels of eosinophilic cationic protein (ECP), (3) lung function ( $\left.\mathrm{FEV}_{1}\right)$ and (4) rating of dyspnoea.

\section{Material and Methods}

\subsection{Study Population}

We randomly selected five public day care in Uppsala, a city with 200000 inhabitants situated in mid-Sweden. A list of all public day care centres in the city was provided by the local government. All staff were invited, all were females and 62 out of 70 the invited subjects participated ( $90 \%)$.

\subsection{Medical Investigation}

All participants answered a general questionnaire with standardized questions on occupation, asthma, chronic diseases, demographic data and the home environment (Wieslander et al., 2011; Norbäck et al., 2015). Each subject was allergy tested in the beginning of the study by skin prick tests (ALK Abello SA, Madrid, Spain) for birch, timothy, mug worth, cat, dog, horse, house dust mites (D. pteronyssinus and D. farinae) and two types of mould (Cladosporium and Alternaria). Details on the allergy testing procedure is available elsewhere (Norbäck et al., 2015). A test result was considered as positive if the mean wheal diameter was more than or equal to $3 \mathrm{~mm}$. Subjects with at least one positive skin prick test were defied as having atopy.

Each participant answered a short medical questionnaire and was invited to the clinical test three times, with a two week interval. All 62 participants fulfilled the study but a few persons each time could not participate in all medical tests for various reasons. The study was a part of a dietary crossover intervention study. For this indoor environment study, clinical data from all three investigations were used since for each participant the three tests were balanced with respect to the dietary intervention (Wieslander et al., 2011).

Information on current symptoms of breathlessness (dyspnoea) was obtained from the short medical questionnaire. Dyspnoea was rated on a 100-mm visual analogue rating scale (VAS-scale) (Nihlen et al., 1998) ranging from 0 to $100 \mathrm{~mm}$. The scale has endpoints graded from "no perceived symptoms at all" (0), to "unbearable symptoms" (100). In addition, it has fixed points with verbal expressions at certain points of the line, 7 means "hardly any", 22 "a few", 50 "many", 78 "a lot" and 93 "a great many" perceived symptoms.

Venous blood was collected in $5 \mathrm{ml}$ SST tubed for analysis of eosinophilic cationic protein (ECP) in serum. Nitric oxide (NO) in exhaled breath (FeNO) was analysed by a portable electrochemical detection device (NIOX-MINO; Aerocrine Ltd, Solna, Sweden) with a flow rate of $50 \mathrm{ml} / \mathrm{min}$. Forced expiratory flow for one second $\left(\mathrm{FEV}_{1}\right)$ was measured by dynamic spirometry. All the tests were carried out in a standardized way by a trained nurse using the same well calibrated spirometer (SPIRA). The measurements were performed three times on each subject each time, and the highest values were noted. A test was considered adequate when the deviation between the two best tests was less than 5\%. The results were expressed as a percentage of normal values based on standardization to age, sex, height, smoking habits and body mass using a local reference material from Uppsala (Hedenström, 1986).

\subsection{Home Environment}

The general questionnaire included questions on environmental tobacco smoke (ETS) and dampness and mould in the current home. Details can be found in previous publications (Norbäck et al., 2005; Wang et al., 2014; Norbäck et al., 1999).

\subsection{Indoor Climate and Dust Collection in the Day Care Centres}

The indoor environment in the day care centre buildings were noted. Indoor and outdoor temperature $\left({ }^{\circ} \mathrm{C}\right)$, relative air humidity ( $\mathrm{RH}, \%)$ and concentration of $\mathrm{CO}_{2}(\mathrm{ppm})$ were measured and average values were calculated for period when the day care centres were occupied by children and staff (Norbäck et al., 2015). Settled dust was collected by vacuum cleaning on a special dust collector (ALK Abello, Copenhagen, Denmark) equipped with a Millipore filter (pore size $6 \mu \mathrm{m}$ ). A $1200 \mathrm{~W}$ vacuum cleaner was used. Vacuum cleaning was performed for 4 minutes per sample, 2 minutes on the floor and 2 minutes on other surfaces (desks, chairs) (Kim 
et al., 2005; Norbäck et al., 2014). Dust was collected from three rooms in each day care centre in the beginning of the study, the same day as the first clinical investigation. Dust was sieved through $0.3-\mathrm{mm}$ mesh screen to obtain the fine dust, weighted, and used for analysis of cat, dog and horse allergens. The sieved dust samples were stored in a freezer $\left(-80^{\circ} \mathrm{C}\right)$. In addition, airborne settling dust was collected in two Petri dishes in each classroom. The Petri dishes were placed on top of open bookshelves or similar areas (height about 1.5-2.0 m) and kept open for 7 days, as previously described (Cai et al., 2011b). The Petri dish samples were kept at room temperature until extraction of the allergens (within a few weeks).

\subsection{Allergen Extraction and Analysis}

The total amount of dust was weighed in each filter sample. Samples of settled dust (100 $\mathrm{mg}$ ) were extracted in 2 $\mathrm{ml}$ of phosphate-buffered saline containing $0.05 \%$ Tween $20(1 / 20 \mathrm{~W} / \mathrm{v})$ for $2 \mathrm{~h}$ at room temperature. The samples were centrifuged at $4500 \mathrm{rpm}$ for $10 \mathrm{~min}$ followed by another at $10,000 \mathrm{rpm}$ for $10 \mathrm{~min}$. The supernatant was transferred to micro-tubes and stored at $20{ }^{\circ} \mathrm{C}$ until analyzed. The Petri dishes were extracted with phosphate buffered saline buffer (PBS, $3 \mathrm{ml}$ ) with $1 \%$ bovine serum albumin (BSA). Then the liquid was transferred into an Eppendorf tube and centrifuged (Cai et al., 2011).The supernatants were stored at $-20{ }^{\circ} \mathrm{C}$ until analysis. Two site sandwich ELISA (Enzyme-Linked Immunosorbent Assay) was applied to determine the levels of cat (Fel d1), $\operatorname{dog}$ (Can f1) (Indoor Biotechnologies Ltd, Manchester, UK), and horse (Equ cx) (Mabtech, Stockholm, Sweden) allergens as previously described (Kim et al., 2005) using monoclonal antibodies. Amplified ELISA was used for cat allergen analysis when the allergen levels were lower than $1.0 \mathrm{ng} / \mathrm{ml}$ by the conventional ELISA (Kim et al., 2005).

\subsection{Statistical Analysis}

Initially, statistical analysis was performed by Mann-Whitney U-test (comparing 2 groups) or by Kendal Tau beta rank correlation test. As a next step, associations between allergens levels and the health parameters were investigated in linear mixed models adjusting for age, body mass index (BMI), current smoking, atopy, environmental tobacco smoke at home, dampness or mould at home and levels of total Fungal DNA and Aspergillus/Penicillium DNA in the vacuumed dust. In our previous article, we found consistent associations between FeNO and two sequences of fungal DNA (total fungal DNA and Aspergillus/Penicillium DNA) in the vacuumed dust (Norbäck et al., 2015). Because of this observation, we adjusted for levels of these two fungal DNA sequences in all models. FeNO, ECP and medical symptoms ratings, but not lung function, were log-transformed $(10-\log )$ and each of the three individual health data measurements were entered in the models (repeated measurement). The variance component on centre level was very small, and thus we analysed associations by one level models, only. The arithmetic mean of the measurements in the rooms was addressed to each day care centre. Coefficients (Beta) with $95 \%$ confidence intervals $(95 \% \mathrm{CI})$ was calculated. Then anti-log data $\left(10^{x}\right)$ for adjusted beta values with $95 \%$ CI were calculated, giving the multiplicative associations with confounders and exposure variables. Statistics were performed with the STATA statistical package using two-tailed tests at a $5 \%$ significance level.

\subsection{Ethics Statement}

The protocol of the study was approved by the Regional Ethical Committee of Uppsala University (2005/65). The researchers informed all invited staff at meetings and collected participants signed consent forms before the investigation. All medical investigations were performed in compliance with the relevant laws and institutional guidelines.

\section{Results}

\subsection{Personal Factors and the Home Environment}

All participants $(\mathrm{N}=62)$ were females and $6 \%$ were current smokers. A total of $16 \%$ had a positive skin prick test to pollen (11\% birch, $8 \%$ timothy and $10 \%$ mug worth), $11 \%$ had a positive skin prick test to cat, $6 \%$ to dog, $2 \%$ to horse and $2 \%$ to house dust mites (D. pteronyssinus and D. farinae). None had a positive skin prick test to mould (Cladosporium or Alternaria). The prevalence of atopy was $18 \%$. Totally $15 \%$ had ETS at home and $29 \%$ reported either window pane condensation, dampness or mould in the current home. Most of the staff (95\%) were preschool teachers or assistant preschool teachers. Two worked in the kitchen and one was employed as cleaner.

\subsection{FeNO Levels, Lung Function, Serum ECP and Symptoms}

The average lung function $\left(\mathrm{FEV}_{1}\right)$ was normal $(104 \%)$ using a local reference material adjusting for age, gender and smoking habits (Hedenström, 1986). The average rating of dyspnoea was relatively low. The geometric mean value for FeNO was 15.3 ppb, and $16 \%$ of the subjects had FeNO levels above the limit value ( $>25 \mathrm{ppb})$ 
suggested by the American Thoracic Society (ATS) (Dweik et al., 2011) (Table 1). Totally 8 subjects (13\%) had ever had asthma diagnosed by a doctor. FeNO was higher ( $\mathrm{p}=0.035$ by Mann-Whitney U-test) among asthmatics $(\mathrm{GM}=20.5 \mathrm{ppb})$ than non-asthmatics $(\mathrm{GM}=14.6 \mathrm{ppb})$.

Table 1. Background variables and study variables in the study $(\mathrm{N}=62)$

\begin{tabular}{ll}
\hline Background variables & Mean (SD) \\
\hline Age & 46 years (10) \\
Body mass index (BMI) & $25.5 \mathrm{~kg} / \mathrm{m}^{2}(4.1)$ \\
& Prevalence (\%) \\
Atopy $^{\mathrm{a}}$ & 18 \\
Current smoker & 6 \\
\hline Study variables & Mean (SD) \\
\hline FEV $_{1}(\mathrm{~L} / \mathrm{s})(\%$ predicted) & $104 \%(14)$ \\
& $\mathrm{GM}(\mathrm{GSD})$ \\
Eye symptoms $^{\mathrm{d}}$ & $10.4 \%(3.40)$ \\
Nasal symptoms & $\mathrm{d}$ \\
Dyspnoea & $9.9 \%(3.87)$ \\
FeNO & $7.4 \%(3.74)$ \\
Serum ECP & $15.3 \mathrm{ppb}(1.78)$ \\
\hline
\end{tabular}

$\mathrm{GM}=$ Geometric mean; GSD=Geometric standard deviation;

${ }^{a}$ At least one positive skin prick test to common allergens (pollen, furry pets, mould or house dust mites);

${ }^{\mathrm{d}}$ Reports on difficulty breathing on a $0-100 \%$ rating scale.

\subsection{Building Characteristics and Allergen Levels}

The buildings were inspected in the beginning of the study. All were one floor buildings with a concrete slab constructed from 1971 to 1991 and all had a mechanical ventilation system with supply-exhaust ventilation. Three of the buildings had poly-vinyl chloride (PVC) floor coating while two had linoleum floors. None of the rooms had visible signs of dampness, visible indoor mould or mould odour. The mean amount of fine dust on the filters was $275 \mathrm{mg} / \mathrm{sample}$ (range 97-495). As a proxy variable for surface contamination, the amount of allergens per sample was calculated by multiplying the allergen concentration in the vacuumed dust with the amount of fine dust and was expressed as amount of allergen (ng) per sample. Data on the allergen levels is given in Table 2. Cat (Fel d 1), dog (Can f 1) and horse allergens (Equ cx) were detected in all vacuumed dust samples (Table 2). To be able to compare with other articles we give median levels for vacuumed dust. Median levels were 852 ng/g Fel d 1, 632 ng/g Can f 1 and 499 ng/g Equ cx. In Petri dish samples, Fel d 1 was found in all samples while Can f1 was detected in 5 samples (33\%) and Equ cx was detected only in two samples (13\%), both from the same day care centre (maximum level $32.4 \mathrm{U} / \mathrm{m}^{2}$ per day). Due to the small number of Petri dish samples with detectable horse allergen, this variable was not further analysed in the statistical models.

\subsection{Correlations between Allergens and Fungal DNA}

There was a positive correlation between cat allergen levels in Petri dish samples $(\mathrm{N}=15)$ and the concentration of cat allergen in vacuumed dust (Kendal Tau beta $0.42 ; \mathrm{p}=0.03$ ) and there was a tendency of a significant correlation between cat allergen in Petri dish samples and amount of cat allergen in vacuumed dust $(\mathrm{p}=0.07)$. In contrast there were no significant correlation between dog allergen in petri dish samples and dog allergen in vacuumed dust, neither as concentration nor as amount of allergen. Moreover, there were significant correlations between different types of allergens in Petri dish samples and in vacuumed dust. There was a positive correlation between amount of cat allergen and dog allergen in vacuumed dust $(\mathrm{p}=0.03)$, between amount of dog allergen and horse in vacuumed dust $(\mathrm{p}=0.01)$ and between amount of horse allergen in vacuumed dust and Cat allergen in Petri dish samples $(\mathrm{p}=0.03)$ Moreover, there was a positive correlation between the concentration of dog allergen and horse allergen in vacuumed dust $(\mathrm{p}=0.02)$ (Table 3). Total fungal DNA and Asp/Pen DNA was 
previously analysed in the vacuumed dust (Norbäck et al., 2015) and in this study we analysed correlation between levels of these two fungal DNA sequences and allergen levels. There were no significant correlation between total fungal DNA or Aspergillus/Penicillium DNA in vacuumed dust and cat, dog or horse allergens in vacuumed or cat or dog allergens in Petri dishes (data not shown).

Table 2. Concentration and amount of allergens in settled dust and Petri dishes $(\mathrm{N}=15)^{\mathrm{a}}$

\begin{tabular}{|c|c|c|}
\hline \multirow{2}{*}{ Type of allergen } & \multicolumn{2}{|c|}{ Concentration in vacuumed dust (ng/g) } \\
\hline & GM (GSD) & Min-Max \\
\hline Cat allergen in dust & $1199(3.55)$ & $141-7244$ \\
\hline Dog allergen in dust & $666(2.11)$ & $155-2502$ \\
\hline \multirow[t]{3}{*}{ Horse allergen in dust } & $478(3.09)$ & $100-4249$ \\
\hline & \multicolumn{2}{|c|}{ Amount in vacuumed dust filters (ng/sample) } \\
\hline & GM (GSD) & Min-Max \\
\hline Cat allergen in dust & $305(4.21)$ & $22-1417$ \\
\hline Dog allergen in dust & $169(2.33)$ & $42-1239$ \\
\hline \multirow[t]{3}{*}{ Horse allergen in dust } & $122(2.63)$ & $30-886$ \\
\hline & \multicolumn{2}{|c|}{ Amount per area $\left(\mathrm{ng} / \mathrm{m}^{2}\right.$ per day) } \\
\hline & GM (GSD) & Min-Max \\
\hline Cat allergen in Petri dish samples & $29.8(3.83)$ & $3.1-290.9$ \\
\hline Dog allergen in Petri dish samples & $9.1(1.86)$ & $6.1-40.9$ \\
\hline
\end{tabular}

$\mathrm{GM}=$ Geometric mean; GSD $=$ Geometric standard deviation;

${ }^{\text {a }}$ Dust was sampled in three randomly selected rooms in each day care centres.

\subsection{Associations between Allergen Levels and FeNO, FEV ${ }_{1}$, Serum ECP and Symptoms}

Associations were analysed between each exposure variable and each health variable, adjusting for age, BMI, smoking, atopy, ETS at home, dampness/mould at home and amount of total Fungal DNA and Aspergillus/Penicillium DNA in the vacuumed dust. Antilog-values of beta coefficients on the log scale with a $95 \%$ CI are given in Table 4 . The amount of cat allergen in vacuumed dust $(\mathrm{p}=0.02)$, and level of cat allergen in Petri dish samples $(\mathrm{p}=0.02)$ were associated with higher FeNO values. In contrast, dog allergen in Petri dish samples was associated with lower FeNO values $(p=0.02)$. Horse allergen in vacuumed dust was associated with lower FeNO values $(\mathrm{p}=0.03)$. There were no associations between amount of fine dust on the filters and any of the four investigated health variables (Table 4). There were no association between lung function $\left(\mathrm{FEV}_{1}\right)$ and cat, dog or horse allergens in vacuumed dust or in Petri dish samples. Finally, significant associations were re-analysed excluding subjects with a positive skin prick test to the particular allergen investigated (e.g. when analysing associations for cat allergen those a positive skin prick test to cat were excluded). Moreover, we re-analysed significant associations excluding all subjects with a positive skin prick test to any of the allergens tested (subject with atopy). All associations remained significant when excluding sensitized subjects. 
Table 3. Correlation (Kendal Tau beta) between different allergens $(\mathrm{N}=15)$

\begin{tabular}{|c|c|c|c|c|c|c|c|c|}
\hline & $\begin{array}{l}\text { Cat allergen in } \\
\text { dust }\end{array}$ & \multicolumn{2}{|c|}{$\begin{array}{l}\text { Dog allergen in } \\
\text { dust }\end{array}$} & $\begin{array}{l}\text { Horse allergen in } \\
\text { dust }\end{array}$ & \multicolumn{2}{|c|}{$\begin{array}{l}\text { Cat allergen in } \\
\text { Petri dish }\end{array}$} & \multicolumn{2}{|c|}{$\begin{array}{l}\text { Dog allergen } \\
\text { Petri dish }\end{array}$} \\
\hline Cat allergen in dust & 1 & & & & & & & \\
\hline \multirow[t]{2}{*}{ Dog allergen in dust } & $0.41 * a$ & \multirow{2}{*}{\multicolumn{2}{|c|}{1}} & & & & & \\
\hline & $0.35\left(^{*}\right) \mathrm{b}$ & & & & & & & \\
\hline \multirow{2}{*}{$\begin{array}{l}\text { Horse allergen in } \\
\text { dust }\end{array}$} & $0.35 \mathrm{a}$ & \multicolumn{2}{|c|}{$0.49 * a$} & 1 & & & & \\
\hline & $0.32(*) b$ & \multicolumn{2}{|c|}{$0.46 * b$} & & & & & \\
\hline \multirow{2}{*}{$\begin{array}{l}\text { Cat allergen in Petri } \\
\text { dish }\end{array}$} & $0.30 \mathrm{a}$ & \multicolumn{2}{|c|}{$0.28 \mathrm{a}$} & $0.41 *$ & \multicolumn{4}{|l|}{1} \\
\hline & $0.42 *$ & \multicolumn{2}{|c|}{$0.39 b$} & 0.31 & & & & \\
\hline \multirow{2}{*}{$\begin{array}{l}\text { Dog allergen in } \\
\text { Petri dish }\end{array}$} & $-0.08 \mathrm{a}$ & \multicolumn{2}{|c|}{$-0.06 a$} & $0.22 \mathrm{a}$ & $-0.18 \mathrm{a}$ & & \multicolumn{2}{|l|}{1} \\
\hline & $-0.07 b$ & \multicolumn{2}{|c|}{$0.18 b$} & $0.25 b$ & \multicolumn{4}{|l|}{$-0.18 b$} \\
\hline \multicolumn{9}{|l|}{$* \mathrm{p}<0.05 ;(*) \mathrm{p}<0.1$} \\
\hline \multicolumn{9}{|c|}{$\begin{array}{l}\text { a Dust data for amount per sample; } \\
{ }^{b} \text { Dust data for concentration in vacuumed dust. }\end{array}$} \\
\hline \multicolumn{9}{|c|}{$\begin{array}{l}\text { Table 4. Associations between dyspnoea, FeNO and serum ECP and allergens in vacuumed dust and Petri dishes, } \\
\text { and amount of fine dust }(\mathrm{N}=62)\end{array}$} \\
\hline Type of allergen & $\begin{array}{l}\text { Dyspnoea Antilog- } \\
(95 \% \mathrm{CI})\end{array}$ & beta & P-value & $\begin{array}{l}\text { FeNO Antilog-beta } \\
(95 \% \mathrm{CI})\end{array}$ & P-value & $\begin{array}{l}\mathrm{ECP} \\
(95 \% \mathrm{CI}\end{array}$ & ntilog-beta & P-value \\
\hline $\begin{array}{l}\text { Cat allergen in } \\
\text { dust }\end{array}$ & $0.82(0.32-2.09)$ & & 0.67 & $1.53(1.06-2.21)$ & 0.02 & $1.00(0.6$ & $-1.56)$ & 0.99 \\
\hline $\begin{array}{l}\text { Cat allergen in } \\
\text { Petri dishes }\end{array}$ & $0.88(0.42-1.86)$ & & 0.74 & $1.40(1.05-1.88)$ & 0.02 & $1.00(0.7$ & $-1.43)$ & 0.99 \\
\hline $\begin{array}{l}\text { Dog allergen in } \\
\text { dust }\end{array}$ & $0.77(0.54-1.09)$ & & 0.14 & $1.08(0.94-1.25)$ & 0.28 & $0.96(0.8$ & $2-1.13)$ & 0.67 \\
\hline $\begin{array}{l}\text { Dog allergen in } \\
\text { Petri dishes }\end{array}$ & $1.20(0.41-3.53)$ & & 0.73 & $0.62(0.41-0.94)$ & 0.02 & $1.00(0.6$ & $-1.66)$ & 0.99 \\
\hline $\begin{array}{l}\text { Horse allergen in } \\
\text { dust }\end{array}$ & $1.82(0.50-6.54)$ & & 0.36 & $0.57(0.34-0.94)$ & 0.03 & $1.05(0.5$ & $3-1.92)$ & 0.86 \\
\hline $\begin{array}{l}\text { Amount of fine } \\
\text { dust }\end{array}$ & $2.34(0.39-14.26)$ & & 0.35 & $1.51(0.73-3.13)$ & 0.70 & $1.20(0.4$ & $3-2.98)$ & 0.29 \\
\hline
\end{tabular}

Adjusted for age, BMI, current smoking, atopy, ETS at home, dampness/mould at home and total fungal DNA and Aspergillus/Penicillium DNA in linear mixed models

(Coefficient calculated for $1000 \mathrm{ng}$ increase of cat allergen (Fel d 1) per gram dust sample)

(Beta value calculated for $100 \mathrm{ng}$ increase of dog allergen (Can $\mathrm{f} 1$ ) per gram dust sample)

(Beta value calculated for $100 \mathrm{U}$ increase of horse allergen (Ecu cx) per gram dust sample)

(Beta value calculated for $100 \mathrm{ng} / \mathrm{m} 2$ per day increase of cat allergen (Fel d 1) in Petri dish samples)

(Beta value calculated for $10 \mathrm{ng} / \mathrm{m} 2$ per day increase of dog allergen (can f 1) in Petri dish samples)

(Beta value calculated for $100 \mathrm{mg}$ increase of vacuumed fine dust per sample)

Coefficients with $95 \% \mathrm{CI}$ are expressed as antilog-beta of 10-logarithm transformed data).

\section{Discussion}

All participants were females, few were smokers, the prevalence of atopy was relatively low (18\%) and the mean 
lung function was normal. A total of $13 \%$ had ever had doctors' diagnosed asthma, somewhat higher than prevalence of doctors' diagnosed asthma $(11.5 \%)$ in a national questionnaire survey in Sweden (Wang et al., 2014). None of the rooms had visible signs of dampness or mould and all five buildings had low $\mathrm{CO}_{2}$ levels (381-505 ppm), levels well below the current ventilation standards saying that $\mathrm{CO}_{2}$ should be below $1000 \mathrm{ppm}$ (ASHRAE, 1989). Previously published measurements from these day care centres (Norbäck et al., 2015) have demonstrated that the $\mathrm{NO}_{2}$ concentration outside all five buildings were low $\left(3-9 \mu \mathrm{g} / \mathrm{m}^{3}\right)$, levels well below the current health-based standards from WHO (annual mean $=40 \mu \mathrm{g} / \mathrm{m}^{3}$ and $200 \mu \mathrm{g} / \mathrm{m}^{3}$ for 1-hour mean) (WHO, 2005).

Selection bias and information bias are important issues in epidemiological studies. We selected the day care centres randomly in a major city in mid-Sweden and the participation rate was high $(90 \%)$. The study was relatively small but each person participated three times which increased the precision of the clinical measurements. The study was a part of a dietary intervention study but the dietary intervention had no influence on FeNO. The medical staff or the participants had no information about any of the indoor measurements when the medical study was performed. Reports on dyspnoea could be influenced by attitudes but it is not likely that clinical data is influenced recall bias. None of the day care centres had any visible signs of dampness or moulds but fungal DNA could be detected in all rooms and we adjusted for levels of fungal DNA in the statistical models. None of the subjects had IgE meditated allergy to two common moulds (Cladosporium sp. and Alternaria sp.). Since exposure to indoor mould can influence respiratory health by other mechanisms than IgE mediated allergy we choose to adjust for levels of fungal DNA in the dust. However, one limitation is that we had no information on levels of bacterial compounds in the dust. We investigated four health parameters and three types of allergens, and the number of statistical tests were limited. Thus, it is less likely that the study was seriously biased by selection bias, information bias or multiple statistical testing but the cross sectional design is a limitation with respect to conclusions on causality.

In this study we sampled cat, dog and horse allergens by two methods; vacuum cleaning on filters and Petri dish sampling. The golden standard is to measure indoor allergen exposure in the air by pumped air sampling but this method is difficult to apply in epidemiological studies. When investigating allergen levels in indoor environments collecting settled dust by vacuum cleaning on special filters is commonly used (Salo et al., 2011). The advantage with this method is that you get relatively large amounts of dust (typically $0.1-1 \mathrm{gram} / \mathrm{sample}$ ) which can be used to analyse different types of compounds or allergens in the same sample. The main disadvantage is that we do not know if the dust has been airborne or not. Sampling of settling airborne dust on Petri dishes exposed to the indoor air for a defined time (typically 1-4 weeks) has been proposed an inexpensive, simple and feasible method for assessing airborne microbial materials from mould or bacteria (Adams et al., 2015). During the last decades, Petri dish sampling has been applied to sample settling airborne allergens (Cai et al., 2011a; Cai et al., 2011b; Elfman et al., 2007; Karlsson et al., 2002; Meritt et al., 2012; Takaoka et al., 2015). In our study, there was a correlation between the concentration of cat allergen (Fel d 1) in vacuumed dust and airborne levels of cat allergen measured by Petri dish sampling (Kendal Tau beta 0.42; $\mathrm{p}<0.05$ ). In contrast, we found no correlation between dog allergen (Can f 1) in vacuumed dust and in Petri dish samples (Kendal-Tau beta 0.18). One validation study from Swedish schools found a good agreement between cat allergen levels measured by Petri dish sampling and air concentrations measured by personal air sampling on filters $(\mathrm{r}=0.66$; $\mathrm{p}<0.0001$ ) (Karlsson et al., 2002). One previous Swedish school study compared concentrations of cat (Fel d 1), $\operatorname{dog}$ (Can f 1) and horse allergens (Equ cx) in vacuumed dust and Petri dish samples. They found significant correlation (Spearman rank correlation test) between these two sampling methods, with correlation coefficients of 0.33 for cat $(\mathrm{p}<0.001), 0.27$ for $\operatorname{dog}(\mathrm{p}=0.003)$ and $0.37(\mathrm{p}<0.001)$ for horse allergen (Elfman et al., 2007).

All dust samples contained cat allergen (Fel d 1). The geometric mean for Fel d 1 was $1199 \mathrm{ng} / \mathrm{g}$ in our study (median $852 \mathrm{ng} / \mathrm{g}$ dust). Similar or higher levels of Fel d 1 have been reported from six other day care centre studies in temperate climate (Munir et al., 1995; Instanes et al., 2005; de Andrade et al., 1995; Perry et al., 2008; Oldfield et al., 2007). Two studies from the tropical country Singapore (Zuraimi et al., 2008; Zhang et al., 1997) found lower levels. Few other studies have measured cat allergen (Fel d 1) in day care centres by the Petri dish methods. The geometric mean for cat allergen (Fel d 1) was $29.8 \mathrm{ng} / \mathrm{m}^{2}$ per day in our study. Another Swedish day care centre study in mid-Sweden (Österåker municipality) found that all Petri dish samples contained Fel d 1, but geometric mean levels were three times lower as compared to our study $\left(9.4 \mathrm{ng} / \mathrm{m}^{2}\right.$ per day) (Cai et al., 2011a).

All vacuumed dust samples contained dog allergen (Can f 1) and the geometric mean was $666 \mathrm{ng} / \mathrm{g}$ dust (median $632 \mathrm{ng} / \mathrm{g}$ dust). Similar or higher levels have been reported from six other day care centre studies from temperate climate (Munir et al., 1995; Instanes et al., 2005; de Andrade et al., 1995; Perry et al., 2008; Oldfield et al., 2007). 
Two studies from Singapore (Zuraimi et al., 2008; Zhang et al., 1997) reported lower levels of Can f 1 . Few studies have measured Can $\mathrm{f} 1$ in in day care centres by the Petri dish method. In our study, only $33 \%$ of the Petri dish samples had detectable levels of Can $\mathrm{f} 1$, and the geometric mean was $9.1 \mathrm{ng} / \mathrm{m}^{2}$ and day. In the Swedish Österåker study, the geometric mean of Can $\mathrm{f} 1$ was similar as in our study $\left(7.2 \mathrm{ng} / \mathrm{m}^{2}\right.$ and day) (Cai et al., 2011a).

Horse allergen (Equ cx) was detected in all vacuumed dust samples (Geometric mean 478 and median $499 \mathrm{U} / \mathrm{g}$ dust) but was found only in a few (13)\% of the Petri dish samples. One recent study measured Equ cx in different particle fractions. The largest particle fraction (above $10 \mu \mathrm{m}$ ) contained much higher levels of horse allergens than the particle mass fraction PM2.5 or the particle fraction between PM2.5 and PM10 (Haeger-Eugensson et al., 2014). Thus it is likely that most of the Equ cx in our study were in larger particles (above $10 \mu \mathrm{m}$ ) and such large particles can be difficult to capture by the Petri dish method. The geometric mean value for Equ cx was $478 \mathrm{Ug} / \mathrm{g}$ in vacuumed dust. We found no other publication on horse allergens in vacuumed dust in day care centres, but Equ cx has been measured in Swedish schools. The geometric mean levels in vacuumed dust was $1343 \mathrm{U} / \mathrm{g}$ dust and $73.9 \mathrm{U} / \mathrm{m}^{2}$ per day in Petri dish samples in Swedish schools (Merrit et al., 2012). In the Swedish Österåker study, Equ cx was detected in $63 \%$ of the Petri dish samples and the geometric mean was $5.0 \mathrm{U} / \mathrm{m}^{2}$ per day (Cai et al., 2011b). The reason for the higher levels of Equ cx in the school study, as compared to our study in day care centres, is unclear. One explanation could be that there is less horse riding in families with pre-school children, since horse riding is an activity for elderly children.

We found consistent positive associations between cat allergen levels (Fel d 1) and FeNO. FeNO is a biomarker of allergic (TH2 driven) inflammation in the lower airways (Alving and Malinovschi, 2006). It is well known that adults sensitized to cat allergen have higher FeNO levels (Malinovschi et al., 2006; Lim et al., 2015) but in our study associations remained significant even when excluding those with a positive skin prick test to cat. This indicate other mechanisms for the observed associations than IgE-mediated cat allergy. It could be either a direct effect of the cat allergen on the immune system, other than via allergic sensitization to cat, or an effect caused by other risk factors correlated with cat allergen levels (confounding). One recent study have demonstrated that allergens can act as immune-modulatory proteins influencing the innate immune system. The study demonstrated that Fel d 1 bind to the toll like receptor (TLR) four (TLR4) agonist lipopolysaccharide, which can explain why Fel d 1 enhance TLR signalling (Herre et al., 22013). Two previous studies from Swedish schools found positive associations between the concentration of Fel $\mathrm{d} 1$ in vacuumed dust from schools and the prevalence of asthma (Smedje et al., 1997) as well as the incidence of asthma (Smedje and Norbäck, 2001 among the students. In contrast, two school environment studies from Asia did not find any association between Fel d 1 in schools and respiratory symptoms among the students (Zhao et al., 2008; Takaoka et al., 2015). In these two studies the level of cat allergen in vacuumed dust was very low (Zhao et al., 2008; Takaoka et al., 2015). We found no previous publication on associations between cat allergen levels in schools or day care centres and FeNO levels in children or staff.

Dog allergen (Can $\mathrm{f} 1$ ) levels in Petri dish samples were associated with lower FeNO levels. A protective effect of dog allergen on respiratory health have not been previously described in day care centres or schools. In contrast, one Swedish school environment study found positive associations between the concentration of Can $\mathrm{f}$ 1 in vacuumed dust and wheeze and day time breathlessness in the students (Kim et al., 2005). Two other school studies from Asia found no association between Can $\mathrm{f} 1$ levels in schools and respiratory symptoms in students (Zhao et al., 2008; Takaoka et al., 2015). To our knowledge, there is no previous publication available on associations between Can $\mathrm{f} 1$ levels in schools or day care centres and FeNO levels in staff or children. One possible explanation is that there was a correlation between dog allergen and bacterial components in dust in our study and that the bacterial compounds could have immune-modulating properties lowering FeNO levels. Dog keeping is associated with increased levels of various bacterial components in home dust, including mycobacteria species DNA, gram positive bacteria DNA, gram negative bacteria DNA and muramic acid, an indicator of gram-positive bacteria (Tischer et al., 2015). Moreover, dogs can be a source of endotoxin in home dust (Chen et al., 2012). One review concluded that dog keeping may reduce development of allergic disease in children (Lodge et al., 2012) and one prospective birth cohort study demonstrated that FeNO at school age was lower in children exposed to endotoxin at age 2-3 months (Casas et al., 2013). The effect of endotoxin depends on genetic disposition and timing so observed effects of endotoxin exposure in early childhood may not be comparable with effects in adults (Radon, 2006). One study among office worker in a tropical area did not find any association between endotoxin levels in office dust and FeNO (Lim et al., 2015).

We found a negative association between horse allergen (Equ cx) and FeNO levels. We found no previous studies on associations between horse allergen exposure in day care centres or schools and FeNO but found one 
intervention study in a horse stable measuring FeNO in workers and riding students. Installation of a mechanical ventilation system reduced the level of Equ cx in air but had no effect on the FeNO levels (Walinder et al., 2011). One school environment study has investigated associations between Equ cx in vacuumed dust and respiratory symptoms. Positive associations were found between levels of Equ cx in vacuumed dust and asthmatic symptoms in the students (Kim et al., 2005).

\section{Conclusions}

Cat, dog and horse allergens were commonly found in Swedish day care centres and different type of allergens may have different associations with FeNO in staff. It could be speculated that allergenic proteins such as Fel d 1, Can $\mathrm{f} 1$ and Equ cx could influence the immune system by other mechanisms than IgE mediated reactions in sensitized subjects, modifying the FeNO level in the airways. Further larger and longitudinal studies are needed to test this hypothesis. Our study suggests that cat allergen (Fel d 1) in day care centres can be a risk factor for lower airway inflammation, measured as FeNO. There is a need for more investigations on possible associations between allergens in schools and day care centres and respiratory health among staff and students.

\section{Acknowledgments}

We are grateful to the local government administration in Uppsala and the day care centre staff for their cooperation. We declare that we have no conflicts of interest.

\section{Conflict of Interest}

The authors declare that there is no conflict of interests regarding the publication of this paper.

\section{References}

Adams, R. I., Tian, Y., Taylor, J. W., Bruns, T. D., Hyvärinen, A., \& Täubel, M. (2015). Passive dust collectors for assessing airborne microbial material. Microbiome, 3, 46. http://dx.doi.org/10.1186/s40168-015-0112-7

Alving, K., \& Malinovschi, A. (2010). Basic aspects of exhaled nitric oxide. In I. Horvath \& J. C. de Jongste (Eds.), Exhaled biomarkers. Eur Respir Mon, 49, 1-31. https://books.google.se/ books?isbn=1849840040

de Andrade, A. D., Charpin, D., Birnbaum, J., Lanteaume, A., Chapman, M., \& Vervloet, D. (1995). Indoor allergen levels in day nurseries. $J$ Allergy Clin Immunol, 95, 1158-1163. http://dx.doi.org/10.1016/S0091-6749(95)70071-4

ASHRAE. Ventilation for acceptable indoor air quality. Atlanta, GA, American Society for Heating, Refrigerating and Air conditioning Engineers, Inc (Standard 62-1999), 1989.

Bröms, K., Svärdsudd, K., Sundelin, C., \& Norbäck, D. (2006). A nationwide study of indoor and outdoor environments in allergen avoidance and conventional daycare centers in Sweden. Indoor Air, 16, 227-235. http://dx.doi.org/10.1111/j.1600-0668.2005.00420.x

Cai, G. H., Bröms, K., Mälarstig, B., Zhao, Z. H., Kim, J. L., Svärdsudd, K., ... Norbäck, D. (2009). Quantitative PCR analysis of fungal DNA in Swedish day care centers and comparison with building characteristics and allergen levels. Indoor Air, 19, 392-400. http://dx.doi.org/10.1111/j.1600-0668.2009.00600.x

Cai, G. H., Mälarstig, B., Kumlin, A., Johansson, I., Janson, C., \& Norbäck, D. (2011a). Fungal DNA and pet allergen levels in Swedish day care centers and associations with building characteristics. J Environ Monit, 13, 2018-2024. http://dx.doi.org/10.1039/c0em00553c

Cai, G. H., Hashim, J. H., Hashim, Z., Ali, F., Bloom, E., Larsson, L., ... Norbäck, D. (2011b). Fungal DNA, allergens, mycotoxins and associations with asthmatic symptoms among pupils in schools from Johor Bahru, Malaysia. Pediatr Allergy Immunol, 22, 290-297. http://dx.doi.org/10.1111/j.1399-3038.2010.01127.x

Casas, L., Tischer, C., Wouters, I. M., Torrent, M., Gehring, M., Garcia-Esteban, R., ... Sunyer, J. (2013). Early life microbial exposure and fractional exhaled nitric oxide in school-age children: A prospective birth cohort study. Environ Health, 12, 103. http://dx.doi.org/10.1186/1476-069X-12-103

Chen, C. M., Thiering, E., Doekes, G., Zock, J. P., Bakolis, I., Norbäck, D., ... Heinrich, J. (2012). Geographical variation and the determinants of domestic endotoxin levels in mattress dust in Europe. Indoor Air, 22, 24-32. http://dx.doi.org/10.1111/j.1600-0668.2011.00740.x

Dweik, R. A., Boggs, P. B., Erzurum, S. C., Irvin, C. G., Leigh, M. W., Lundberg, J. O., ... American Thoracic Society Committee on Interpretation of Exhaled Nitric Oxide Levels (FENO) for Clinical Applications (2011). An Official ATS clinical practice Guideline: Interpretation of exhaled nitric oxide levels (FE(NO)) for clinical applications. Am $J$ Respir Crit Care Med, 184, 602e15. 
http://dx.doi.org/10.1164/rcem.9120-11ST

Elfman, L., Mi, Y., Norbäck, D., \& Smedje, G. (2007). World Allergy Organ J, 610, S194-S195. Retrieved from http://www.waojournal.org/content/pdf/1939-4551-1-A1.pdf

Haeger-Eugensson, M., Ferm, M., \& Elfman, L. (2014). Use of a 3-D dispersion model for calculation of distribution of horse allergen and odor around horse facilities. Int J Environ Res Public Health, 11, 3599-3617. http://dx.doi.org/10.3390/ijerph110403599

Hedenström, H. (1986). Selection of lung function tests and interpretation of their results. In Acta Upsaliensis Alwqvist \& Wiksell, Stockholm, Sweden, 1986 (pp. 1-29). (A PhD thesis from the Department of Clinical Physiology, Uppsala University).

Herre, J., Grönlund, H., Brooks, H., Hopkins, L., Waggoner, L., Murton, B., ... Bryant, C. (2013). Allergens as immune-modulatory proteins: The cat dander protein Fel d 1 enhances toll-like receptor activation by lipid ligands. J Immunol, 191, 1529-1535. http://dx.doi.org/10.4049/jimmunol.1300284

Instanes, C., Hetland, G., Berntsen, S., Lovik, M., \& Nafstad, P. (2005). Allergens and endotoxin in settled dust from day-care centers and schools in Oslo, Norway. Indoor Air, 15, 356-362. http://dx.doi.org/10.1111/j.1600-0668.2005.00381.x

Karlsson, A. S., Hedren, M., Almqvist, C., Larsson K., \& Renström, A. (2002). Evaluation of Petri dish sampling for assessment of cat allergen in airborne dust. Allergy, 57, 164-1678. http://dx.doi.org/10.1034/j.1398-9995.2002.1s3297.x

Kelly, L.A., Erwin, E. A., \& Platts-Mills, T. A. E. (2012). The indoor air and asthma: The role of cat allergens. Curr Opin Pulm Med, 18, 29-34. http://dx.doi.org/10.1097/MCP.0b013e32834db10d

Kim, J. L., Elfman, L., Mi, Y., Johansson, M., Smedje, G., \& Norbäck, D. (2005). Current asthma and respiratory symptoms among pupils in relation to dietary factors and allergens in the school environment. Indoor Air, 15, 170-182. http://dx.doi.org/ 10.1111/j.1600-0668.2005.00334.x

Konradsen, J. R., Fujisawa, T., van Hage, M., Hedlin, G., Hilger, C., Kleine-Tebbe, J., ... Platts-Mills, T. A. (2015). Allergy to furry animals: New insights, diagnostic approaches and challenges. J Allergy Clin Immunol, 135, 616-625. http://dx.doi.org/10.1016/j.jaci.2014.08.026

Li, C. S., Hsu, C. W. \& Lu, C. H. (1997a). Dampness and respiratory symptoms among workers in daycare centers in a subtropical climate. Arch Environ Health, 52, 68-71. http://dx.doi.org/10.1080/00039899709603803

Li, C.S., Hsu, C. W. \& Tai, M. L. (1997b). Indoor pollution and sick building syndrome symptoms among workers in day-care centres. Arch Environ Health, 52, 200-207. http://dx.doi.org/10.1080/00039899709602887

Liccardi, G., Salzillo, A., Dente, B., Piccolo, A., Lobefalo, G., Noschese, P., ... D’Amato, G. (2009). Horse allergens: an underestimated risk for allergic sensitization in an urban atopic population without occupational exposure. Respiratory Medicine, 103, 414-420. http://dx.doi.org/10.1016/j.rmed.2008.09.017

Lim, F. L., Hashim, Z., Said, S. M., Than, L. T. H., Hashim, J. H., \& Norbäck, D. (2015). Fractional exhaled nitric oxide (FeNO) among office workers in an academic institution, Malaysia - associations with asthma, allergies and office environment. $J$ Asthma, Aug 24 (Epub ahead of print).

Lodge, C. J., Allen, K. J., Lowe, A. J., Hill, D. J., Hosking, C. S., Abrahamson, M. J., \& Dharmage, S. C. (2012). Perinatal cat and dog exposure and the risk of asthma and allergy in the urban environment: a systematic review of longitudinal studies. Clin Dev Immunol, 176484. http://dx.doi.org/10.1155/2012/176484

Malinovschi, A., Janson, C, Holmkvist, T., Norbäck, D., Meriläinen, P., \& Högman, M. (2006). IgE sensitization in relation to flow-independent nitric oxide exchange parameters. Respiratory Research, 7, 92. http://dx.doi.org/10.1186/1465-9921-7-92

Merritt, A. S., Emenius, G., Elfman, L., \& Smedje, G. (2012). Measurements of horse allergen (Equ cx) in schools. ISRN Allergy, 574258. http://dx.doi.org/10.5402/2011/574258

Munir, A. K., Einarsson, R., \& Dreborg, S. K. (1995). Mite (Der p 1, Der f 1), cat (Fel d 1) and dog (Can f 1) allergens in dust from Swedish day-care centres. Clin Exp Allergy, 25, 119-126. http://dx.doi.org/10.1111/j.1365-2222.1995.tb01016.x

Nihlen, A., Walinder, R., Löf, A., \& Johanson, G. (1998). Experimental exposure to methyl tertiary-butyl ether II. 
Acute effects in humans. Toxicol Appl Pharmacol, 148, 281-287. http://dx.doi.org/10.1006/taap.1997.8342

Norbäck, D., Björnsson, E., Janson, C., Palmgren, U., \& Boman, G. (1999). Current asthma and signs of inflammation in relation to building dampness in dwellings. Int J Tubercl Lung Dis, 3, 368-376.

Norbäck, D., Markowicz, P., Cai, G. H., Hashim, Z., Ali, F., Zheng, Y. W., ... Hashim, J. H. (2014). Endotoxin, ergosterol, fungal DNA and allergens in dust from schools in Johor Bahru, Malaysia-associations with asthma and respiratory infections in pupils. PLoS One, 9, e883303. http://dx.doi.org/10.1371/journal.pone.0088303

Norbäck, D., Cai, G. H., Kreft, I., Lampa, E., \& Wieslander, G. (2015). Fungal DNA in dust in Swedish day care centres: associations with respiratory symptoms, fractional exhaled nitrogen oxide (FeNO) and C-reactive protein in serum among day care centre staff. Int Arch Occup Environ Health, (Jul 17 (Epub ahead of print). http://dx.doi.org/10.1007/s00420-015-1076-4

Oldfield, K., Siebers, R., \& Crane J. (2007). Endotoxin and indoor allergen levels in kindergartens and daycare centres in Wellington, New Zealand. N Z Med J, 120, U2400.

Perry, T. T., Vargas, P. A., Bufford, J., Field, C., Flick, M., Simpson, P. M., ... Jones, S. M. (2008). Classroom allergen exposure in Arkansas head start centers. Ann Allergy Clin Immunol, 100, 358-363. http://dx.doi.org/10.1016/S1081-1206(10)60599-6

Radon, K. (2006). The two sides of the "endotoxin coin". Occup Environ Med, 63, 73-78. http://dx.doi.org/10.1136/oem.2004.017616

Ruotsalainen, R., Jaakkola, N., \& Jaakkola, J. J. (1995). Dampness and molds in day-care centres as an occupational health problem. Int Arch Occup Environ Health, 66, 369-374.

Salo, P. M., Sever, M. L., \& Zeldin, D. C. (2011). Indoor allergens in school and day care environments. $J$ Allergy Clin Immunol, 124, 185-192. http://dx.doi.org/10.1016/j.jaci.2009.05.012

Smedje, G., Norbäck, D., \& Edling, D. (1997). Asthma among secondary schoolchildren in relation to the school environment. Clin Exp Allergy, 27, 1270-1278. http://dx.doi.org/ 10.1111/j.1365-2222.1997.tb01171.x

Smedje, G., \& Norbäck, D. (2001) Incidence of asthma diagnosis and self-reported allergy in relation to the school environment-a four-year follow-up study in schoolchildren. Int J Tubercl Lung Dis, 5, 1059-1066.

Takaoka, M., Suzuki, K., \& Norbäck, D. (2015). Sick building syndrome among junior high school students in Japan in relation to the home and school environment. Global $J$ Health Sci, 8, 46131. http://dx.doi.org/10.5539/gjhs.v8n2p165

Tischer, C., Zock, J. P., Valkonen, M., Doekes, G., Guerra, S., Heederik, D., ... Heinrich, J. (2015). Predictors of microbial agents in dust and respiratory health in the Ecrhs. BMC Pulmonary Medicine, 15, 48. http://dx.doi.org/10.1186/s12890-015-0042-y

Walinder, R., Riihimäki, M., Bohlin, S., Hogstedt, C., Nordquist, T., Raine, A., ... Elfman, L. (2011). Installation of mechanical ventilation in a horse stable: Effects on air quality and human and equine airways. Environ Health Prev Med, 16, 264-272. http://dx.doi.org/10.1007/s12199-010-0195-5

Wang, J., Engvall, K., Smedje, G., \& Norbäck, D. (2014). Rhinitis, asthma and respiratory infections among adults in relation to the home environment in multi-family buildings in Sweden. PLoS One, 9, e105125. http://dx.doi.org/10.1371/journal.pone.0105125

WHO. WHO Air Quality Guidelines Global Update 2005. World Health Organization 2005, Denmark. http://www.euro.who.int/_data/assets/pdf_file/0017/43325/E92646.pdf

Wieslander, G., Fabjan, N., Vogrincic, M., Kreft, I., Janson, C., Spetz-Nyström, U., ... Norbäck, D. (2011) Eating buckwheat cookies is associated with the reduction in serum levels of myeloperoxidase and cholesterol: A double blind crossover study in day-care centre staffs. Tohoku $J$ Exp Med, 225, 123-130. http://dx.doi.org/10.1620/tjem.225.123.org/10.1620/tjem.225.123oi.org/10.1620/tjem.225.123

Zahradnik, E., \& Raulf, M. (2014). Animal allergens and their presence in the environment. Front Immunol, 5 , 76. http://dx.doi.org/ 10.3389/fimmu.2014.00076

Zang, L., Chew, F. T., Soh, S. Y., Yi, F. C., Law, S. Y., Goh, D. Y., \& Lee, B. W. (1997). Prevalence and distribution of indoor allergens in Singapore. Clin Exp Allergy, 27, 876-885. http://dx.doi.org/10.1111/j.1365-2222.1997.tb01227.x

Zhao, Z., Sebastian, A., Larsson, L., Wang, Z., Zhang, Z. \& Norbäck, D. (2008). Asthmatic symptoms among 
pupils in relation to microbial dust exposure in schools in Taiyuan, China. Pediatr Allergy Immunol, 19, 455-465. http://dx.doi.org/10.1111/j.1399-3038.2007.00664.x

Zuraimi, M. S., Ong, T. C., Tham, K. W., \& Chew, F. T. (2008). Determinants of indoor allergens in tropical child care centres. Pediatr Allergy Immunol, 19, 746-755. http://dx.doi.org/ 10.1111/j.1399-3038.2007.00714.x

\section{Copyrights}

Copyright for this article is retained by the author(s), with first publication rights granted to the journal.

This is an open-access article distributed under the terms and conditions of the Creative Commons Attribution license (http://creativecommons.org/licenses/by/3.0/). 